\title{
CONCORRÊNCIA FISCAL, COMPETITIVIDADE E COESÃO SOCIAL NA UNIÃO EUROPEIA
}

\author{
MARIA DO ROSÁRIO ANJOS \\ PROFESSORA ASSOCIADA DA FACULDADE DE DIREITO E CIÊNCIA POLÍTICA DA \\ UNIVERSIDADE LUSÓFONA DO PORTO \\ INVESTIGADORA DO IJP - INSTITUTO JURÍDICO PORTUCALENSE E DO CEAD FRANCISCO SUÁREZ. ADVOGADA \\ E ÁRBITRO DO CAAD EM MATÉRIA ADMINISTRATIVA E TRIBUTÁRIA.
}

\begin{abstract}
This study presents an evolutionary synthesis of the measures adopted to tax legislation harmonization between the member states of the European Union in the last decades. Considering the tax system as an essential instrument for the competitiveness of companies and decision-making on the location and realization of foreign investment. It is intended to demonstrate how tax competition between the Member States of the European Union has harmed the achievement of greater economic cohesion and became a serious threat to the survival of the European Union project.

KEYWORDS: Social cohesion; Competitiviness; Fiscal Competition; Tax Law Harmonization

RESUMO: No presente estudo apresenta-se uma síntese evolutiva das medidas adotadas para harmonização das legislações fiscais dos Estados membros da União Europeia nas últimas décadas. Considerando o sistema fiscal um instrumento essencial para a competitividade das empresas e tomada de decisão sobre a localização e realização do investimento, em particular do investimento estrangeiro. Pretende-se demonstrar como a concorrência fiscal entre os Estados membros da União Europeia tem prejudicado a livre concorrência no mercado da EU, a competitividade e a coesão económica e social e, nessa medida, constitui uma ameaça séria à sobrevivência do projeto da EU.
\end{abstract}

KEYWORDS: Coesão social; Competitividade; Concorrência fiscal; Harmonização fiscal.

SUMÁRIO: 1. Fiscalidade, Concorrência e Competitividade: abordagem introdutória. 2. Fiscalidade na EU: falha de harmonização de legislações fiscais na EU. 3. Sobre o conceito de Harmonização versus Aproximação de legislações no âmbito do Direito da União Europeia. 3.1 O IVA. 3.2 Os Impostos Especiais sobre o Consumo. 3.3 A Harmonização da Tributação Direta. 3.4. A Tributação de Pessoas Singulares. 4. Fiscalidade Justa e Concorrência Fiscal Prejudicial. 5. Impacto da concorrência fiscal sobre a competitividade. 6. Os efeitos da Pandemia COVID 19 na Política Fiscal na União Europeia. Conclusões

\section{Fiscalidade, Concorrência e Competitividade: abordagem introdutório}

O poder de tributar é uma emanação da soberania de Estado, do qual é muito difícil abdicar, ainda que parcialmente, mesmo quando se integra uma organização com as características da União Europeia (UE). Desde a versão original do Tratado fundador (Tratado de Roma) o poder de tributar permaneceu nas mãos dos Estados-Membros. As sucessivas revisões do Tratado fundador não alteraram esta situação. No Tratado sobre o Funcionamento da União Europeia (TFUE), também designado por Tratado de Lisboa, esta regra não foi alterada, cabendo à UE apenas de competências muito limitadas nesta matéria

S sistema fiscal é fundamental para a competitividade e para uma concorrência leal entre as empresas que operam na UE. Nas últimas décadas, as diferenças de tributação entre os diferentes Estados membros, a utilização de benefícios fiscais e regimes especiais de tributação mais favorável, têm sido utilizadas como instrumento de concorrência desleal entre os Estados membros. A solução para evitar os efeitos perversos da concorrência fiscal no seio a EU passa por harmonizar as legislações fiscais dos diferentes Estados membros ou, por criar regimes comuns de tributação, usando a Diretiva como instrumento de aproximação das legislações entre os Estados membros.

Ao longo das décadas foi este o caminho seguido, de forma gradual, tímida e por vezes ineficaz, como veremos. 
A falta de capacidade em adotar medidas mais determinadas e uniformizadas em matéria fiscal, mormente em áreas essenciais ao desenvolvimento económico e competitividade das empresas e das economias, conduziu ao fracasso das políticas europeias em prol de uma maior coesão económica e social.

A concorrência fiscal resulta da tributação diferenciada dos rendimentos, concretamente, sucede quando um país oferece taxas mais baixas de tributação, com o objetivo de captação de rendimentos de outros países, de modo a reforçar o capital disponível para investimento na sua economia. Para que o sistema fiscal seja mais competitivo os Estados recorrem a taxas mais reduzidas de tributação e ao reconhecimento de benefícios fiscais, funcionando estes últimos como uma forma indireta de auxílios do Estado a determinados agentes económicos.

Uma vez que a política fiscal da UE tem por objetivo o bom funcionamento do mercado único, a harmonização da tributação indireta foi considerada prioritária relativamente à tributação direta. Podemos dizer que se verificou um esforço de harmonização fiscal, mais acentuada na fiscalidade indireta, com alguns tópicos da fiscalidade direta.

A luta contra a evasão e a elisão fiscais tornou-se, das últimas duas décadas, uma prioridade política.

Com os recentes acontecimentos relativos ao escândalo "LuxLeaks", a questão dos auxílios de Estado sob forma fiscal e a concorrência fiscal prejudicial tornaram-se em tópicos verdadeiramente prementes. É sobre ambos que nos debruçaremos, numa análise atualista que permitirá clarificar e conciliar os conceitos.

Novas questões se foram colocando a concorrência fiscal desleal no seio da própria EU. Do mesmo modo surge uma nova atenção para os auxílios de estado disfarçados pela concessão de benefícios fiscais. Se aliarmos a complexidade dos auxílios de Estado aplicados à fiscalidade das empresas, com a crescente globalização das atividades económicas, e a proliferação de empresas que operam para além das fronteiras nacionais, somos levados a constatar que esta realidade se apresenta cada vez mais como um sério desafio para as jurisdições fiscais dos vários Estados Membros e para a atuação das instituições europeias. Não há dúvida que as diferentes regras fiscais em vigor nos Estados membros têm efeitos muito negativos sobre a concorrência e a competitividade das empresas e das economias.

A falta de harmonização fiscal efetiva é ainda mais grave no seio dos países da zona euro. Sem possibilidade de lançar mão dos tradicionais instrumentos de estabilização da economia, tais como a taxa de câmbio e controlados pela imposição de cumprimento dos mesmos critérios de estabilidade, os países da zona euro passaram a usar o sistema fiscal como instrumento para tornar a economia de cada Estado membro mais atraente para os

investidores. Desta forma o sistema fiscal transformou-se num instrumento de competição, desigual, entre os diferentes Estados membros ${ }^{1}$.

A fiscalidade interfere com a livre concorrência e, nessa medida, acaba por afetar a competitividade das economias na EU, e em particular na Zona Euro. As diferenças significativas nos regimes fiscais dos Estados membros evidenciam uma manifesta concorrência fiscal entre si, embora esta ocorra sem aparente violação do Direito da União Europeia. Desta forma, os Estados membros (EM) utilizam o sistema fiscal como arma comercial e de concorrência entre si, equivalente aos anteriores instrumentos de competição entre si.

Esta questão não é nova e a consciência da importância da harmonização fiscal no seio da União Europeia é reconhecida pelas instituições europeias ${ }^{2}$, pela doutrina $^{3}$ e pela jurisprudência do Tribunal de Justiça, desde a primeira década da construção do projeto europeu ${ }^{4}$.

Os avanços até ao presente não foram suficientes para acautelar as distorções da concorrência decorrentes dos diferentes regimes fiscais, com destaque para a fiscalidade direta. Apesar de ser uma preocupação evidente desde a primeira hora, a verdade é que, muitas das condicionantes políticas e institucionais para avançar no sentido da harmonização fiscal ou da aproximação das legislações continuam por superar, o que dificulta o processo ${ }^{5}$.

A globalização e suas consequências recentes reacenderam a discussão em torno da necessidade de maior harmonização das legislações fiscais dos EM, bem assim como a necessidade de obter níveis mínimos de tributação sobre o rendimento das empresas a nível global. ${ }^{6}$ Será este o impulso que faltava para avançar com uma efetiva harmonização fiscal na EU?

${ }^{1}$ Alena, A., Lucia, M., \& Slavomíra, M. (2017). Meta-analysis categorization of EU countries in the context of corporate income tax. Contaduría y Administración, 62/3), 1001-1018. hitps://doi.org/10.1016/..cya.2017.04.002

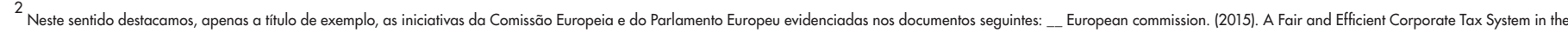

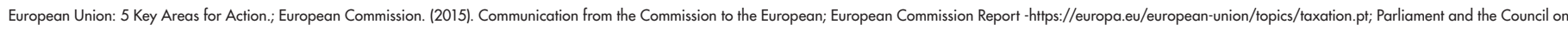
a Fair and Efficient Corporate Tax System in the European Union: 5 Key Areas for Action \{COM(2015) 302 final\}. ${ }^{34}$ JO L 345 de 29/12/2011.

3 Verhoeven, "Communauté Européennes et Rapprochement dês Legislations", Bruxelas, 1983. No mesmo sentido, Waelbroeck. (1986) L'Harmonisation dês Régles et Normes Techniques dans la CEE, Doctrine, Bruxelas

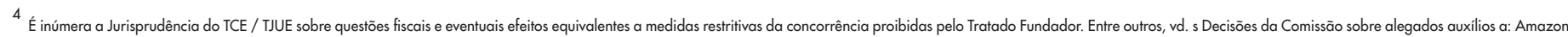
no Luxemburgo, de 7.10.2014, C(2014)7165, Apple na Irlanda e Starbucks na Holanda, de 11.6.2014, respetivamente C(2014)3606 e C(2014)3626 


\section{Fiscalidade na EU: falha de harmonização de legislações fiscais na EU}

Desde a primeira hora foi clara a opção pelo que muitos autores classificam como harmonização na fiscalidade indireta como instrumento indispensável à concretização dos objetivos prioritários do mercado único europeu, isto é, na constituição e sedimentação do projeto europeu.

Entre os impostos indiretos figuram o imposto sobre o valor acrescentado e os impostos especiais de consumo (álcool, o tabaco, automóvel, entre outros). $\bigcirc$ sistema comum de IVA é, em geral, aplicável aos bens e serviços comprados e vendidos para utilização ou consumo na UE.

Os impostos especiais de consumo incidem sobre a venda ou utilização de produtos específicos. As atividades legislativas da UE visam coordenar e aproximar a legislação sobre o IVA, bem como harmonizar os impostos especiais de consumo sobre o álcool, o tabaco e a energia, a fim de assegurar um funcionamento correto do mercado interno.

Basta pensar no quanto o peso do custo da energia onera o custo de produção das empresas portuguesas, comparativamente à maioria dos Estados membros da EU.

Por outro lado, as diferenças de regime de dedução de imposto entre os EM é um outro fator extremamente importante com impacto no custo de produção final. Logo afeta a competitividade das empresas no mercado único com desvantagem para os países mais pobres e menos desenvolvidos. ${ }^{7}$

A ideia de que os países mais ricos o são porque pagam impostos muito elevados é um equívoco, atualmente reconhecido por diversos autores. ${ }^{8} \mathrm{Na}$ verdade, temos, isso sim, países pobres com taxação típica de países ricos enquanto estes, pelo menos alguns deles, tentam reduzir a sua taxação tornando-a mais "friendly" para os investidores estrangeiros e para o grande capital. São exemplo disso, o Luxemburgo, A Irlanda e a Holanda, que se destacam por oferecer uma fiscalidade muito "soft and friendly» para as empresas que escolham os seus países como sede e domicilio fiscal da sua atividade.
Outros EM, como a Polónia, a Hungria, Eslováquia, Eslovénia, Croácia, Chipre, entre outros apresentam bons desempenho de crescimento económico, com níveis de tributação mais baixos do que Portugal e políticas de benefícios fiscais aos investidores estrangeiros /considerando-se como tal qualquer investidor de outro EM da EU ou de qualquer outra parte do Mundo). ${ }^{9}$

Desde já se esclarece que, do nosso ponto de vista, face à ausência de harmonização fiscal efetiva, é totalmente legítimo a cada EM optar pela política fiscal que considere mais adequada aos seus interesses. Quando tantas vozes se erguem contra as discrepâncias fiscais entre os EM, convém deixar claro que nenhum sentido faz criticar este ou aquele EM por optar por uma fiscalidade mais suave e amiga do investimento privado. Os que reclamam contra esta opção podiam e deviam adotar idênticas políticas de tributação, para se manterem tão competitivos como aqueles a quem dirigem essas criticas. Alternativamente, a única resposta possível e justa para resolver a concorrência fiscal na EU é, sem qualquer dúvida, avançar no sentido de uma harmonização fiscal efetiva no seio da EU. Uma coisa é certa enquanto existirem estas disparidades não se construirá uma EU efetiva, justa e mais coesa.

Como alcançar a almejada coesão económica e social com esta realidade? A base jurídica para a harmonização fiscal resulta do disposto no artigo $113^{\circ}$ do Tratado sobre o Funcionamento da União Europeia (TFUE) ${ }^{10}$, o qual dispõe que: «O Conselho, deliberando por unanimidade, de acordo com um processo legislativo especial, e após consulta do Parlamento Europeu e do Comité Económico e Social, adota as disposições relacionadas com a harmonização das legislações relativas aos impostos sobre o volume de negócios, aos impostos especiais de consumo e a outros impostos indiretos, na medida em que essa harmonização seja necessária para assegurar o estabelecimento e o funcionamento do mercado interno e para evitar as distorções de concorrência.»

Por sua vez 0 artigo $114^{\circ}$ do TFUE $^{11}$, inicia $~$ Capítulo 3 do TFUE sobre a aproximação das legislações, dispondo que «1. Salvo disposição em contrário dos Tratados, aplicam-se as disposições seguintes à realização dos objetivos enunciados no artigo $26^{\circ}$. O Parlamento Europeu e o Conselho, deliberando de

5 Haan e Sturm, "The Political and Institutional Constraints of Fiscal Policy in EEC", in Public Choice Review, 1993.

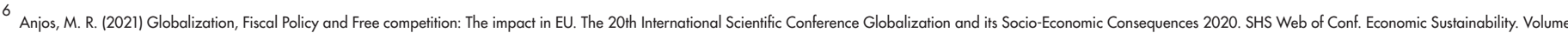
92,2021

DOI: https://doi.org/10.1051/shsconf/20219208001

7 Monagha (2012). Aftraction and Retention of Foreign Direct Investment (FDI): The Role of Subnational Institutions in a Small, Highly Globalised Economy. Irish Journal of Management.

8 Mendoza, G. E. \& Razin, Assaf \& Tesar, L. L. (1994). Effective tax rates in macroeconomics: Cross-country estimates of tax rates on factor incomes and consumption. Journal of Monetary Economics, 34(3), 297-323. 
acordo com o processo legislativo ordinário, e após consulta do Comité Económico e Social, adotam as medidas relativas à aproximação das disposições legislativas, regulamentares e administrativas dos Estados-Membros, que tenham por objeto o estabelecimento e o funcionamento do mercado interno. (...)».

Os artigos $115^{\circ}$ a $118^{\circ}$ do TFUE concretizam e completam a base jurídica necessária à eliminação de qualquer discrepância legislativa entre os EM que possa resultar em distorção da concorrência, prejudicial ao funcionamento do mercado interno no seio da EU.

Mas, a harmonização de legislações em matéria fiscal ficou muito aquém do necessário para garantir uma competitividade entre as empresas da EU, sem distorções fiscais suscetíveis de conduzir a efeitos equivalentes, porventura mais perversos do que os resultantes dos antigos impostos aduaneiros. ${ }^{12}$ Mais preocupante é perceber o quanto a UE regrediu no percurso inicialmente traçado de aproximação das legislações em todos os campos necessários a integração e garantia de livre concorrência no mercado único. Se comparamos os avanços alcançados nas primeiras décadas de integração europeia com as últimas duas décadas, conclui-se que o processo de aproximação das leis fiscais foi travado e eternamente adiado. ${ }^{13}$

Note-se que são inúmeras as iniciativas meramente programáticas inscritas em relatórios estudos e outros documentos europeus. Contudo, além do tempo e do dinheiro gasto em reuniões, cimeiras e encontros inúteis, muito pouco se avançou. De notar que nem a dupla tributação conseguiu ser eficazmente evitada entre Estados membros da EU. ${ }^{14}$ Algo tão básico como isso, continua a ser um problema, e a ineficácia da comunicação entre as autoridades dos diferentes Estados membros é um problema real e preocupante. ${ }^{15}$

Do que vem exposto resulta evidente que as diferenças de legislação fiscal entre os EM podem conduzir e potenciar distorções da concorrência nefastas ao funcionamento do mercado único europeu. ${ }^{16}$

A evolução das últimas décadas acentuou as diferenças entre os regimes fiscais dos EM, promovendo uma concorrência desleal, com consequências no crescimento e estabilidade económica e no investimento estrangeiro. ${ }^{17}$

Hoje a União Europeia está mais desigual, desunida, enfraquecida, mergulhada em querelas jurídico-constitucionais que se julgava ultrapassadas, em risco sério de desintegração. A maior e melhor construção da Europa do século XX, um projeto de paz e prosperidade para a Europa, está em risco de sucumbir face à inoperância e incompetência dos dirigentes do século XXI.

As soluções são conhecidas, bastaria coragem para avançar no sentido certo, harmonizando ou mesmo unificando os regimes fiscais, na medida suficiente e necessária para pôr termo a uma competição fratricida e perigosa.

que fizeram as Instituições Europeias nos últimos 20 anos para contrariar esta situação?

Os avanços foram muito tímidos, insuficientes e, com a zona euro em pleno funcionamento, não se compreende que neste conjunto de países que a integram a harmonização fiscal não tenha avançado de forma efetiva. ${ }^{18}$

A resposta que podemos avançar é igual à que poderíamos dar há 20 anos atrás, ou seja, que pouco ou nada se avançou na eliminação das condicionantes políticas e institucionais que impedem (ou, pelo menos, dificultam) o avanço da harmonização fiscal na EU. ${ }^{19}$

No pensamento dos pais fundadores da integração europeia, destacando Jean Monnet, "estava a criação de uma organização supranacional robusta que "não fizesse, mas fizesse fazer", isto é, com poderes decisórios fortes, mas executando as suas políticas através das máquinas administrativas dos Estados membros”. ${ }^{20}$ Apesar de tudo que vem exposto e das dificuldades evidenciadas no processo de coesão algumas iniciativas de relevo foram assumidas ao longo das décadas que se seguiram à fundação da Comunidade Económica Europeia e posterior União Europeia.

Importa, assim, mencionar os momentos essenciais desses avanços, não só para conhecer melhor a evolução deste processo de aproximação das legislações fiscais, mas também para concluir se este processo se desenvolve regularmente e ponderadamente ao longo do tempo ou se foi negligenciado, apesar dos efeitos profundamente nefastos para a livre e leal concorrência no seio da EU.

9

Csomós, B. \& Kiss, G. (2014). Evolution of the Hungarian Tax Structure after 2010. KözGazdaság, (4).

10 Corresponde ao antigo artigo $93^{\circ}$ do TCE.

11 Corresponde ao antigo artigo $95^{\circ}$ do TCE.

12 Ibidem.

13 Delgado, F. J., Fernandez-Rodriguez, E., \& Martinez-Arias, A. (2014). Effective tax rates in corporate taxation: A quantile regression for the EU. Engineering Economics, 25(5), 487-496. https://doi.org/10.5755/j01.ee.25.5.4531

14 Csomós, B. \& Kiss, G. (2014). Evolution of the Hungarian Tax Structure after 2010. KözGazdaság, (4) 


\section{Sobre o conceito de Harmonização versus Aproximação de legislações no âmbito do Direito da União Europeia}

Importa referir que o conceito de harmonização de legislações apela, segundo a doutrina dominante, a algo mais do que a mera aproximação de legislações. Simplificando, podemos dizer que a harmonização resulta da introdução de regimes jurídicos comuns e igualmente aplicáveis em todos os Estados aderentes. No caso da EU, esse objetivo é alcançado através da adoção de Regulamentos europeus.

Quando a intenção é aproximar os regimes jurídicos dos diferentes Estados membros, o instrumento utilizado é a Diretiva, a qual é dirigida aos Estados membros e impõe a sua transposição interna, na qual dispõem sempre de uma margem de livre regulamentação interna, da qual resultam, naturalmente, diferenças assinaláveis de regime jurídico entre os diferentes Estados membros.

Deve-se esclarecer que a aproximação legislativa significa compatibilizar ordens jurídicas nacionais em prol de escopos compartilhados, pela vocação internacional das relações humanas, balizadas pelo direito. trata-se de conceito amplo, conformando-se em gênero, do qual são espécies a coordenação e a harmonização.

No âmbito da tributação, estamos no plano da mera aproximação de legislações, operada através de Diretivas e do reconhecimento de ampla margem de regulamentação reservada aos Estados membros. A coordenação difere da harmonização em termos de amplitude, consistindo esta em processo mais abrangente do que aquela. Isso porque tem como objeto suprimir ou atenuar as assimetrias entre as disposições legislativas internas, na medida em que o exija o funcionamento do bloco econômico.

A harmonização pode ser compreendida em sentido amplo e estrito. Em sentido amplo, refere-se à adoção de medidas para redução ou eliminação de divergências entre normas internas, resultando na coexistência afinada de sistemas autônomos e independentes; em sentido estrito, compreende as medidas voltadas para eliminação de conflitos entre regras de sistemas nacionais distintos, para promover a coexistência de regras de mesmo sentido.

Contudo, não há, na doutrina, pleno consenso acerca do conceito de harmonização. Além da coordenação e harmonização, também são espécies de aproximação normativa a uniformização e a unificação. A uniformização é o conjunto de disposições legislativas adotadas pelos Estados para submissão de certas relações jurídicas a uma mesma regulamentação. Ou seja, segundo alguns Autores, trata-se do procedimento pelo qual diversos legisladores adotam uma norma formulada do mesmo modo, ou um único legislador introduz em vários ordenamentos normas formuladas de modo idêntico. ${ }^{21}$ Já unificação constitui processo mais intenso, por representar a adoção de legislação única. Isto é, consiste na criação de uma norma única, aplicada sob os cuidados de autoridades pertencentes a uma única hierarquia, destinada a substituir uma pluralidade de normas divergentes e autónomas. ${ }^{22}$

Ao fim de décadas de construção de uma União Europeia esta parece estar cada vez mais aprisionada pelas condicionantes políticas e institucionais ${ }^{23}$ que insistentemente impedem avançar no sentido da harmonização, senão mesmo unificação, dos regimes fiscais na EU.

De todo o modo, façamos uma breve incursão histórica para assimilar as principais iniciativas e tentativas (algumas alcançadas e outras não) de harmonização fiscal na europa comunitária, desde a sua fundação até aos nossos dias. Face à abrangência do tema, a análise será limitada aos impostos que mais interferem com a competitividade das empresas, com impacto na concorrência fiscal e na coesão social no seio da EU. Nesta perspetiva, os impostos indiretos situam-se num plano essencial e foram a primordial preocupação das instituições europeias

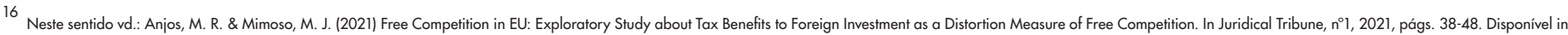
http://hdl.handle.net/11328/3501. ISSN 2734-8830 (Online); Anjos, M. R. (2019). Free Competition and Fiscal Policy in European Union. In D. Dukic, T. Studzieniecki \& J. Grzinic (Eds.), Economic and Social Development 49th International

Scientific Conference on Economic and Social Development Development - "Building Resilient Society" (pp. 254-262). Varazdin: Varazdin Development and Entrepreneurship Agency.

17 Russu, C. (2016). Foreign Direct Investment in the European Union. Economic Insights. Trends and Challenges, 5(1), 51-63.

18 A propósito dos avanços ténues e insuficientes em sede de harmonização fiscal e dos efeitos perversos sobre a competitividade, concorrência, crescimento económico e coesão no seio da EU, destacamos: Schwab, K. (2017). The Global Competitiveness Report 2017-2018. World Economic Forum (Vol. 5). https://doi.org/92-95044-35-5; Stoilova, D. (2017). Tax structure and economic growth: Evidence from the European Union. Contaduría y Administración e Sulimana, A. H. Elianb, M. I., \& Alic, H. E. (2018). Endogenous Specification of FDI and Economic Growth : Cross-Economies ' Evidence. Internation Journal of Business, 23-39.

19 Dyreng, S. D., Hanlon, M., Maydew, E. L., \& T., \& R., J. (2017). Changes in corporate effective tax rates over the past 25 years. Journal of Financial Economics, 124(3), 441-463. https://doi.org/10.1016/i.jfineco.2017.04.001

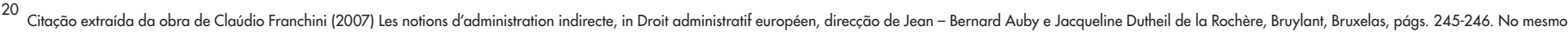
sentido, cfr. Jacques Ziller (2007) Introduction: les concepts d'administration directe, d'administration indirecte et de co-administration et les fondements du droit administrative européen", in Droit administratif européen, direcção de Jean - Bernard Auby e Jacqueline Dutheil de la Rochère, Bruylant, Bruxelas, pág. 246. 


\subsection{O IVA}

Uma breve incursão sobre a evolução do processo de harmonização fiscal no seio da EU permite evidenciar a lenta evolução deste processo.

Na verdade, a concretização na Comunidade Económica Europeia, assente nas quatro liberdades, das quais a livre circulação de mercadorias foi a primeira efetiva concretização do projeto de integração europeia, impôs a harmonização da tributação indireta. A introdução do imposto sobre o valor acrescentado (IVA) como imposto geral sobre o consumo, decorreu em várias etapas, de modo a garantir a transparência no comércio interno. Várias décadas decorridas, ainda hoje, são frequentes as questões colocadas por alguns EM a propósito da correta aplicação da Diretiva IVA, nas suas sucessivas versões. Esta dificuldade de perceção do alcance da introdução deste imposto como base indispensável para a concretização da integração económica e do funcionamento do mercado único evidencia a dificuldade que os EM (ou, pelo menos, alguns) têm em abdicar dos seus próprios interesses de arrecadação tributária. Apesar disso, este foi e continua a ser o melhor exemplo de harmonização fiscal no seio da EU, pese embora as diferenças ressalvadas aos EM, que usam de alguma margem de liberdade na definição de certas normas internas.

Em 1970, foi tomada a decisão de financiar o orçamento da Comunidade Económica Europeia a partir dos recursos próprios da Comunidade. Estes recursos deveriam incluir pagamentos baseados numa proporção do IVA e obtidos através da aplicação de uma taxa comum de imposto a uma matéria coletável uniforme. A Diretiva IVA (2006/112/CE), adotada em 2007, codifica num único ato legislativo as modificações introduzidas.

Em 1985, a Comissão publicou o «livro Branco sobre o Mercado Único» COM(1985) 0310 - cuja Parte III é consagrada à supressão das fronteiras fiscais.
A necessidade de adoção de medidas no domínio do IVA decorreu da aplicação do "princípio do país de destino".

Em 1987, a Comissão propôs a transição para o "princípio do país de origem» segundo o qual as transações entre os Estados-Membros seriam sujeitas ao imposto já aplicado no país de origem, que os operadores poderiam posteriormente deduzir como imposto suportado. A Comissão propôs, além disso, a introdução de um mecanismo de compensação, tendo em vista a reafectação do IVA cobrado nos países de origem aos países de consumo. Estas propostas eram, porém, inaceitáveis para os Estados-Membros. A solução apresentada retinha, a título alternativo, o princípio do país de destino para transações que envolvessem operadores registados para efeitos de IVA e estabeleceu as bases do sistema transitório, que se tornou operacional em 1993 (Diretivas 91/680/CEE e 92/111/ CEE).

A partir de 2000, a Comissão esforçou-se por instituir medidas visando melhorar o regime «transitório» em vigor. Entretanto, a Diretiva IVA 2006/112/CE tornou-se o texto legislativo mais importante da UE em matéria de IVA. Em 2008, seguiram-se as Diretivas 2008/8/CE e 2008/9/CE. Doravante, o IVA sobre os serviços entre profissionais é aplicado no país em o serviço é prestado.

Em 2005, foi estabelecida a base para uma aplicação mais uniforme das regras da UE (Regulamento de Execução (UE) n. ${ }^{\circ}$ 282/2011). Todos os Estados-Membros tinham então a possibilidade de aplicar medidas especiais destinadas a simplificar a aplicação do IVA. A adoção do Regulamento (CE) n. 37/2009 relativo à cooperação administrativa no domínio do imposto sobre o valor acrescentado, que visa lutar contra a fraude fiscal ligada às operações intracomunitárias, permitiu melhorar o sistema.

Mas, mesmo nesta esfera de fiscalidade indireta, dita "harmonizada", importa salientar que essa harmonização é imperfeita sobre muitos aspetos, com destaque

21 Hodžid, S. (2011). Harmonization of corporate tax general guidelines in the UE and harmonization in Germany, Austria and Italy. Our Economy (Nase Gospodarstvo), 58(1), 64-71.

22 Ibidem.

23 Haan, J., Sturm, J. (1994). The Political and Institutional Constraints of Fiscal Policy in the European Union. Public Choice Review, 80(1-2), 157-172.

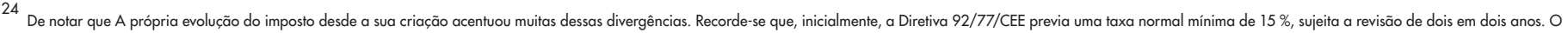
Conselho prorrogou subsequentemente o período de validade da taxa normal mínima até ao final de 2017 . Além disso, os Estados-Membros poderiam aplicar uma ou duas taxas reduzidas, não inferiores a $5 \%$, a determinados bens e serviços. Os Estados-Membros puderam continuar a aplicar taxas inferiores a uma taxa mínima (incluindo zero) a bens e serviços que vigoravam antes de 1 de janeiro de 1991. 
para a divergência em matéria de taxas de imposto e regras de dedutibilidade do imposto. ${ }^{24}$

Já em 2009, foi adotada a Diretiva 2009/47/CE relativa às taxas reduzidas do imposto sobre o valor acrescentado para os serviços prestados a nível local e com grande intensidade de mão-de-obra.

Em 2010, a Comissão publicou um Livro Verde sobre o futuro do IVA - COM (2010) 0695, com o objetivo predominante de lançar um debate sobre o regime do IVA tal qual fora introduzido no seio dos EM. Em 2012, a Comissão criou um grupo de peritos sobre o IVA, designado por "Comité do IVA», que tem vindo a publicar regularmente orientações, mas sem resultados concretos no que respeita a avanços da aproximação dos códigos de IVA vigentes nos diferentes EM.

Em suma, do que vem exposto concluímos que apesar de todos os esforços das instituições europeias pouco se avançou para além do que tinha sido implementado anteriormente. As resistências a um maior grau de harmonização da tributação indireta dos Estados permanecem muito acentuadas.

Em 7 de abril de 2016, a Comissão apresentou um Plano de Ação para a modernização do sistema de IVA na UE. Este plano foi inspirado pela vontade de definir um conjunto de princípios enformadores de um futuro "sistema comum europeu de IVA». Nos termos deste plano avança-se com um conjunto de medidas a curto prazo de luta contra a fraude ao IVA (preocupação dominante), proposta de planos de revisão das taxas reduzidas de IVA e um conjunto de propostas de simplificação das regras de IVA. O aspeto central da proposta refere, ainda, a aplicação do princípio do país do destino no que respeita às entregas transfronteiriças.

A partir de 2017, a Comissão e o Conselho apresentaram diversas propostas legislativas, sempre marcadas pela intenção de simplificação e modernização das regras do imposto (por exemplo, no âmbito do comércio eletrónico) na tentativa de promover uma maior harmonização no sistema do IVA.

Também o Parlamento Europeu tem tido uma intervenção ativa no sentido de suportar, apoiar e melhorar as propostas da Comissão, sobretudo na intenção de avançar para um sistema comum e definitivo de IVA, bem como medidas adicionais para combater a fraude em sede do imposto. ${ }^{25}$

Em suma, apesar de todas as iniciativas louváveis das instituições europeias, com destaque para a Comissão, na realidade, a resistência dos Estados membros apenas permitiu apenas "pequenos passos» no sentido da maior harmonização fiscal, os quais podem fazer alguma diferença, mas não o suficiente para garantir uma efetiva neutralidade do imposto no seio da EU o que só se atingir com um sistema único de IVA. De todo o modo, é em sede de tributação indireta e, concretamente, em sede de IVA, que se atingiu o maior grau de harmonização fiscal no seio da EU.

\subsection{Os Impostos Especiais sobre o Consumo}

Ainda em matéria de tributação indireta há que fazer uma breve referência, ainda que breve, aos impostos especiais de consumo. Também estes são diferentes em cada Estado membro, o que, naturalmente, afeta a concorrência no mercado interno.

A existência de grandes discrepâncias no imposto sobre um determinado produto pode resultar na circulação de mercadorias induzida pelos impostos, na perda de receitas e em fraude. Foram desenvolvidos esforços desde o início dos anos 70 tendo em vista harmonizar as estruturas e as taxas, embora os progressos neste domínio tenham sido bastante modestos.

A Diretiva 2008/118/CE relativa ao regime geral dos impostos especiais de consumo veio estabelecer um regime geral para os produtos sujeitos a impostos especiais de consumo, a fim de garantir a sua livre circulação e, por conseguinte, o bom funcionamento do mercado interno na UE. Em maio de 2018, a Comissão propôs uma reformulação da Diretiva 2008/118/CE. Em novembro de 2019, - Conselho adotou uma alteração ao Regulamento (UE) n. 389/2012 sobre a supervisão da circulação de produtos sujeitos a impostos especiais de consumo após a introdução no consumo num Estado-Membro.

Uma das principais dificuldades no que se refere ao álcool é a questão de saber em que medida os diferentes produtos estão em concorrência. Só em 1992 é que foi adotada a Diretiva 92/83/CEE, que determina sobre que produtos são tributados impostos especiais e segundo que método. Seguiu-se uma outra importante diretiva (92/84/CEE). Uma proposta visando modificar a Diretiva 92/85/CEE laproximação das taxas do imposto especial sobre o consumo de álcool e bebidas alcoólicas) foi retirada em março de 2015, porquanto o Conselho não conseguiu chegar a acordo.

No âmbito do programa para a adequação e a eficácia da regulamentação (REFIT), a Comissão procedeu a uma avaliação da Diretiva 92/83/CEE, e, em maio de 218, apresentou uma proposta de alteração da diretiva. Em novembro de 2019, o Conselho chegou a acordo sobre a proposta.

No que se refere ao tabaco a estrutura básica da tributação foi agrupada numa diretiva consolidada (2011/64/UE). Contrariamente às propostas iniciais da Comissão, foram apenas fixadas taxas mínimas. Existem várias categorias de tabaco manufaturado sujeitas a tributação. Os impostos sobre os cigarros são compostos por uma taxa proporcional, "ad valorem», juntamente com um imposto específico sobre o consumo. $\bigcirc$ consumo de outros tabacos manufaturados está sujeito a um imposto especial "ad valorem», específico ou misto.

Seguindo a mesma lógica subjacente aos impostos especiais de consumo sobre o álcool, a avaliação REFIT evidenciou possibilidades de revisão da Diretiva relativa 
aos produtos do tabaco. $\bigcirc$ Conselho convidou a Comissão a efetuar os trabalhos preparatórios tendo em vista uma eventual proposta legislativa. Em janeiro de 2018, após ter procedido a uma avaliação, a Comissão decidiu não propor a revisão ou a alteração da Diretiva 2011/64/UE devido à falta de dados.

Também Produtos energéticos lóleos minerais, gás, eletricidade, energias alternativas, combustível para aeronaves)

A estrutura de base do imposto especial de consumo aplicável aos óleos minerais na Comunidade foi estabelecida em 1992. Não obstante, como no caso do álcool e do tabaco, foram apenas fixadas taxas mínimas, contrariamente aos planos iniciais (harmonização completa). As propostas da Comissão de 1997 foram aprovadas com amplas modificações (Diretiva 2003/96/CE, derrogações nas Diretivas 2004/74/CE e 2004/75/CE).

A Comunicação da Comissão publicada em 2000 sobre a tributação dos combustíveis para aeronaves COM (2000/0110) limitou-se a constatar que a Diretiva 2003/96/CE prevê uma isenção fiscal obrigatória para "produtos energéticos fornecidos para utilização como carburantes para a navegação aérea, com exceção da aviação de recreio privada». Introduziu pela primeira vez disposições que permitem que os Estados-Membros tributem o combustível para voos domésticos e, por meio de acordos bilaterais, o combustível para voos intracomunitários.

Em 2001, foram propostas medidas com vista à promoção da utilização de biocombustíveis que incluíam a possibilidade da aplicação de uma taxa reduzida do imposto especial sobre o consumo, medidas essas que foram adotadas em 2003 através da Diretiva 2003/30/CE.

Na sua resolução de 2002 sobre a política fiscal da UE, o Parlamento declara não concordar com a política da Comissão em matéria de impostos especiais de consumo sobre o tabaco e sobre os produtos alcoólicos, não sendo, em particular, favorável a uma harmonização para cima. Em 2009, o Parlamento manifestou-se favorável a um aumento gradual dos impostos sobre os cigarros e outros produtos do tabaco, ainda que não ao nível da proposta da Comissão.

Em conclusão, podemos dizer que nos impostos especiais sobre o consumo também se verifica algum esforço de harmonização, apesar de subsistirem diferenças assinaláveis entre a tributação dos diferentes Estados membros.

A jurisprudência do TJUE evidencia alguns dos problemas que surgem neste domínio. É o caso, por exemplo, do Imposto sobre a importação de veículos em relação ao qual Portugal tem sido recorrentemente visado em muitas do TJUE, quase todas desfavoráveis à posição alegada por Portugal. ${ }^{26}$

\subsection{A Harmonização da Tributação Direta}

No domínio da tributação direta os avanços foram significativamente menores. âmbito da tributação do rendimento das pessoas coletivas e singulares é uma matéria sensível e não é diretamente regulamentado pela legislação europeia. No entanto, várias diretivas e a jurisprudência do Tribunal de Justiça da União Europeia estão a estabelecer normas harmonizadas para o imposto sobre o rendimento das sociedades e para o imposto sobre o rendimento das pessoas singulares. Além disso, foram tomadas algumas ações para prevenir a evasão fiscal e a dupla tributação.

Não existe no Tratado da União Europeia qualquer disposição explícita sobre competências legislativas no domínio dos impostos diretos. A legislação relativa à tributação das sociedades baseia-se habitualmente no artigo 115. do Tratado sobre - Funcionamento da União Europeia (TFUE), que permite a adoção de diretivas para a aproximação das disposições legislativas, regulamentares e administrativas dos Estados-Membros que tenham incidência direta no funcionamento do mercado interno; estas preveem a unanimidade e o processo de consulta.

O artigo 65. ${ }^{\circ}$ do TFUE (livre circulação de capitais) permite aos Estados-Membros distinguir entre contribuintes que não se encontrem em idêntica situação no que se refere ao seu lugar de residência ou ao lugar em que o seu capital é investido. No entanto, em 1995, o TJUE determinou (Processo C-279/93) que o artigo 45. do TFUE é diretamente aplicável no domínio da tributação e da segurança social. Este artigo estipula que a livre circulação dos trabalhadores implica «a abolição de toda e qualquer discriminação em razão da nacionalidade (...) no que diz respeito ao emprego, à remuneração e demais condições de trabalho".

Os artigos 110. a 113. do TFUE estipulam que os Estados-Membros devem entabular negociações para a eliminação da dupla tributação no interior da União Europeia.

artigo 55. do TFUE proíbe a discriminação entre os nacionais dos EstadosMembros no que diz respeito à participação financeira no capital das 
sociedades. ${ }^{27}$

Apesar do que vem exposto, a verdade é que a larga maioria das disposições em matéria de tributação direta está, no entanto, fora do âmbito do direito da UE. Uma vasta rede de Tratados fiscais bilaterais, que tanto envolvem EstadosMembros como países terceiros, cobre a tributação dos fluxos de rendimentos transfronteiriços. Contudo, importa referir que o sucesso destes Tratados têm revelado uma escassa eficácia e não têm cumprido a missão para os quais foram e ainda são vistos como instrumentos de regulação internacional das relações fiscais internacionais.

Assim, podemos dizer que estes tratados visam cumprir dois objetivos específicos: a prevenção da evasão fiscal e a eliminação da dupla tributação.

Mas, em todos estes instrumentos de regulação e aproximação das legislações fiscais dos diferentes EM da EU se refere, de um modo geral, que esta aproximação, ou uma certa harmonização da tributação das empresas se justifica, ainda, como forma a evitar as distorções de concorrência (especialmente no que respeita às decisões de investimento), bem como impedir a erosão das receitas através da "concorrência fiscal» e reduzir as possibilidades de manipulação contabilística. ${ }^{28}$ As propostas de harmonização do imposto sobre as sociedades são debatidas há várias décadas (1962: Relatório Neumark; 1970: relatório van den Tempel; 1975: proposta de Diretiva relativa a um alinhamento das taxas de imposto). Em 1980, a Comissão reconheceu que esta tentativa de harmonização estaria condenada ao fracasso (COM (80)0139) e concentrou-se em medidas para realizar o mercado interno de capitais. Nas "Orientações em matéria de fiscalidade das empresas» de 1990 (SEC (90)0601) foram adotadas três propostas, nomeadamente a Diretiva relativa às fusões (90/434/CEE, atual Diretiva 2009/133/CE), a Diretiva relativa às sociedades mães e sociedades afiliadas (Diretiva 2011/96/UE), e a Convenção sobre o processo de arbitragem (90/436/CEE). Todos estes passos foram precedidos de duras negociações com os Estados-Membros é a proposta de diretiva relativa ao regime fiscal comum aplicável às sociedades-mãe e sociedades afiliadas de Estados-Membros diferentes, de 1991. Apesar de ter sido revista e de ter merecido um parecer favorável do Parlamento Europeu, a Comissão acabou por retirar esta proposta devido à falta de acordo no Conselho. Em 1998, foi apresentada uma nova versão, integrada no "Pacote Monti», a qual foi aprovada como Diretiva 2003/49/CE.

Ainda em 1991, foi criado o comité de peritos independentes Ruding. $\bigcirc$ primeiro relatório apresentado recomendou um programa de ação para eliminar a dupla tributação, harmonizar as taxas do imposto sobre o rendimento das sociedades e assegurar a total transparência dos benefícios fiscais previstos pelos EstadosMembros para promover o investimento. Por esta altura, também a Comissão apresentou um conjunto de propostas que foram posteriormente retiradas e só em 1996 conseguiu apresentar uma nova abordagem à fiscalidade.

No domínio da tributação das sociedades, o principal resultado foi o Código de Conduta para a Tributação das Empresas, adotado sob a forma de resolução do Conselho de janeiro de 1998. O Conselho instituiu um grupo sobre o código de conduta (conhecido como "Grupo Primarolo») para examinar casos participados de tributação injusta das empresas. Em 2001, a Comissão elaborou «um estudo analítico da fiscalidade das empresas na Comunidade Europeia» (SEC (2001)1681). Na sua comunicação complementar (COM (2001)0582), a Comissão concluiu que os principais problemas das empresas se deviam ao facto de terem de se adaptar a diferentes regulamentações nacionais no mercado interno.

A Comissão propôs várias abordagens para dotar as empresas de uma matéria coletável comum consolidada para as suas atividades a nível da UE: tributação pelo Estado de residência, uma tributação da matéria coletável comum consolidada em regime facultativo (MCCIS), um imposto europeu sobre o rendimento das sociedades e uma matéria coletável obrigatória e totalmente harmonizada. Em 2004, foi criado um grupo de trabalho, cujas conclusões foram

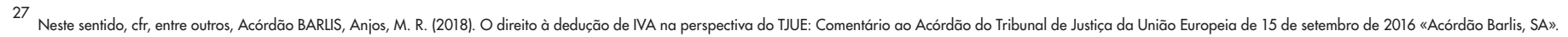
Revista da Faculdade de Direito e Ciência Polífica da Universidade Lusófona do Porto, 2(10), 108-125. Disponível no Repositório UPT, http://hdl.handle.net/11328/2360 http://hdll.handle.net/11328/2360

28 Neste sentido, cfr. Sørensen, P. B. (2001). Tax coordination in the European Union: What are the issues? SWEDISH ECONOMIC POLICY REVIEW, 8, 143-195.

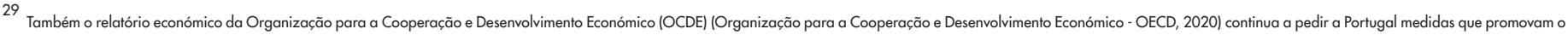
investimento externo no país. Os fatores problemáticos identificados para a realização de investimento em Portugal apontam, entre outros, para a falta de clareza das medidas fiscais de incentivos ao investimento, ou seja, uma fiscalidade complexa, opaca e que frequentemente viola as expectativas dos investidores e destrói a confiança no sistema fiscal, agravado pela tradicional falência e morosidade da justiça.

30

A título de exemplo, em Portugal uma família com matéria coletável igual ou superior a $80.000,00$ euros anuais é tributada no último escalão do IRS, a uma taxa de $48 \%$. Nos termos do disposto no artigo $68^{\circ}$-A do CIRS, à taxa referida acresce 2,5\%, para matérias coletáveis compreendidas entre 80.000,00 e 250.000,00 e 5\% a matérias coletáveis superiores a 250.000,00. Por exemplo, na Alemanha a taxa do último escalão é idêntica à Portuguesa, mas o patamar de rendimento a partir do qual se aplica é bem diferente: $256.304,00$ euros. Este exemplo reproduz-se quando estabelecemos comparação com outros países da EU. 
integradas na proposta de diretiva da Comissão (COM (2011) 0121. Nesta diretiva a proposta «matéria coletável comum consolidada do imposto sobre as sociedades» significaria que as empresas beneficiam de um sistema de balcão central onde poderiam apresentar os seus pedidos de reembolso de impostos. Poderiam igualmente consolidar todos os lucros e prejuízos que tenham registado na UE. Os Estados-Membros teriam toda a competência pela fixação dos impostos a pagar pelas suas próprias sociedades. A resolução legislativa do Parlamento Europeu sobre este assunto foi aprovada em abril de 2012.

Em junho de 2015, para relançar as negociações no Conselho, a Comissão apresentou uma estratégia para uma revisão da proposta MCCCIS em 2016. A proposta deverá conter uma MCCCIS obrigatória, mas esta poderá ser introduzida gradualmente. A proposta, adaptada aos trabalhos da OCDE, também poderia ser contraproducente para o combate à elisão fiscal, ao eliminar o espaço de manobra existente entre os sistemas nacionais, enfraquecendo assim as disposições correntemente adotadas para combater a elisão fiscal. Em março de 2018, a Comissão propôs duas diretivas ao conselho destinadas a assegurar uma tributação justa das empresas que disponibilizam serviços digitais.

A UE continua a trabalhar no sentido de uma solução global para a tributação dos serviços digitais no âmbito do G20/ da OCDE. Em outubro de 2019, a vicepresidente executiva da Comissão comprometeu-se a elaborar uma proposta da UE sobre tributação dos serviços digitais se não for alcançado um acordo global até ao final de 2020 .

Apesar de todas as iniciativas descritas, constata-se, que as divergências fiscais permanecem e nenhum dos problemas, verdadeiramente, se encontra resolvido, permanecendo uma concorrência fiscal na EU inaceitável. No plano do combate evasão fiscal os avanços têm sido muito lentos, pois, falha algo básico e anterior para ganhar esse combate: maior harmonização das legislações fiscais no seio da EU.

A Comissão liderada por Úrsula Van der Leyen parece ter consciência do que falta para garantir políticas mais eficazes no combate à evasão, elisão, fuga de rendimentos não declarados para paraísos fiscais e criminalidade fiscal, como bem resulta do conjunto de medidas consideradas como prioritárias, aprovadas em 15 de julho de $2020 .{ }^{29}$

\subsection{A Tributação de Pessoas Singulares}

A tributação das pessoas que trabalham num Estado-Membro ou dele recebem uma pensão, mas que vivem ou têm familiares dependentes num outro EstadoMembro tem sido uma questão controversa. Embora os acordos bilaterais evitem em geral a dupla tributação, não resolvem questões como a da aplicação de diversos benefícios fiscais no país de residência ao rendimento auferido no país de emprego. Para assegurar a igualdade de tratamento entre trabalhadores residentes e não residentes, a Comissão propôs uma Diretiva relativa à harmonização das disposições fiscais sobre o rendimento no que se refere à liberdade de circulação (COM (79)0737), que previa a tributação no país de residência. A proposta foi retirada após a sua rejeição pelo Conselho, tendo a Comissão apenas publicado uma recomendação sobre os princípios a aplicar ao tratamento fiscal do rendimento dos não residentes. Além disso, foram intentados processos contra alguns EstadosMembros por discriminação contra os trabalhadores não nacionais. Em 1993, o TJUE deliberou (Processo C-112/91) que um país não podia impor a não nacionais de outro Estado-Membro um regime menos favorável de tributação direta do que o dos seus próprios nacionais (Processo C-279/93). Por conseguinte, a integração das pessoas singulares no domínio da tributação direta evoluiu mais em virtude dos acórdãos do TJUE do que das propostas legislativas. Em outubro de 2017, o Conselho adotou uma diretiva (Diretiva (UE) 2017/1852) destinada a melhorar os ałuais mecanismos de resolução de litígios em matéria de dupla tributação na UE.

\section{Fiscalidade Justa e Concorrência Fiscal Prejudicial}

Na sequência da crise financeira de 2008, as atenções centraram-se na luta contra a evasão fiscal e numa tributação uniforme das empresas. Isto deve ser alcançado, nomeadamente, através de mais transparência, tal como evidencia - pacote de medidas para melhorar a transparência, de março de 2015, que inclui a diretiva do Conselho relativa à troca automática de informações entre

31 Cfr.: Sørensen, P. B. (2009). Dual Income Taxes: A Nordic Tax System. University of Copenhagen, Economic Policy, 2009-10, 1-34.

32 Dados divulgados pela AMECO - Comissão Europeia disponíveis em: https://ec.europa.eu/info/business-economy-euro/indicators-statistics/economic-databases/macro-economic-database-ameco_pt

33 Klemm, A. (2010). Causes, benefits, and risks of business tax incentives. International Tax and Public Finance, 17(3), 315-336. https://doi.org/10.1007/s10797-010-9135-

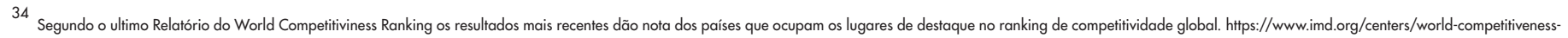
center/rankings/world-competitiveness/. 
os Estados-Membros sobre decisões fiscais (Diretiva (UE) 2015/2376) e a comunicação relativa à transparência fiscal destinada a combater a fraude fiscal e a evasão fiscal. Em 2015, a Comissão apresentou um Plano de Ação para uma tributação das sociedades justa e eficaz na UE, que previa uma reforma do quadro fiscal para as empresas da UE para combater o abuso fiscal, garantir receitas sustentáveis e apoiar um melhor enquadramento empresarial no mercado interno. Em janeiro de 2016, a Comissão apresentou o seu pacote de medidas contra a elisão fiscal, que prevê, nomeadamente, uma proposta de diretiva de luta contra as práticas de elisão fiscal, que afetam diretamente o funcionamento do mercado interno (adotada em julho de 2016).

Em abril de 2016, a Comissão propôs uma alteração à Diretiva 2013/34/ UE no que respeita à divulgação de informações relativas ao imposto sobre o rendimento por determinadas empresas e sucursais. A proposta exige que as empresas multinacionais divulguem ao público certos elementos das informações comunicadas às autoridades fiscais. Em junho de 2017, a Comissão propôs novas regras de transparência para os intermediários (por exemplo, empresas de consultoria, bancos, advogados, consultores fiscais) que concebem ou vendem regimes fiscais potencialmente prejudiciais, na sequência de um pedido de proposta legislativa apresentado na resolução do Parlamento (TAXE2). A proposta foi adotada pelo Conselho em maio de 2018. Em dezembro de 2017, o Conselho publicou a primeira lista da UE de jurisdições não cooperantes. A lista é atualizada periodicamente.

Após esta rápida passagem pelas iniciativas das últimas décadas para aproximar os regimes fiscais dos Estados Membros, os avanços foram ténues e de escassa eficácia.

O problema da concorrência fiscal no seio da EU tornou-se ainda mais agressiva depois da criação do euro e. É imperativo que os regimes fiscais dos EstadosMembros sejam conformes com as regras da UE em matéria concorrência e isso implica que não seja permitido qualquer tipo de práticas com efeitos equivalentes aos auxílios estatais proibidos pelo direito da EU. A concorrência fiscal agressiva é uma prática disfarçada de auxílios de Estado. No quadro das investigações que a Comissão tem vindo a realizar sobre o problema e as formas de o resolver ou minimizar, destaca-se sobre os acordos fiscais prévios para determinadas empresas, o Parlamento Europeu instituiu uma comissão temporária: Comissão Especial sobre as Decisões Fiscais Antecipadas e Outras Medidas de Natureza ou Efeitos Similares (a Comissão TAXE) e a subsequente Comissão TAXE2.

Não se pretende desviar o foco de análise para outras questões que, por si só, justificam uma análise detalhada e específica, como seja o combate à erosão das bases tributárias, evasão fiscal e planeamento fiscal abusivo. Contudo, não há dúvida que, tendo as instituições europeias concentrado os seus esforços dantescos na luta contra a elisão e evasão fiscais, a verdade é que os resultados obtidos até ao momento são, eufemisticamente, fracos e pouco expressivos. A explicação, na verdade, é simples: sem harmonização fiscal efetiva entre os Estados membros da EU nenhuma política de combate à evasão ou erosão fiscal surtirá verdadeiro efeito útil. Afinal, sem essa harmonização sempre haverá possibilidade de contornar qualquer instrumento (por natureza burocrático e moroso) de controlo dos comportamentos abusivos em sede fiscal.

Mas, se é assim, a questão fundamental (the million-dollar question") é a de saber a razão pela qual não se avançou muito mais no sentido da harmonização fiscal? A resposta é óbvia: porque alguns Estados membros ganham com isso e têm vindo a garantir o seu nível de competitividade, em todos os indicadores relevantes, à custa da concorrência fiscal que praticam. Logo, só se vislumbra uma de duas soluções: ou avançamos no sentido de maior harmonização fiscal lou mesmo "unificação fiscal») ou seguimos a política de uma fiscalidade mais atrativa, à semelhança do que tem sido a política seguida por Estados membros como a Irlanda, Holanda ou Luxemburgo.

Claro que, a explicação politicamente correta, assenta na alegação da necessidade da receita fiscal para fazer face ao Estado Social e às responsabilidades da República Portuguesa. Pura demagogia ou cegueira ideológica, porquanto a realidade prova que Portugal é hoje um dos países com piores condições de vida e menos atrativos para os recursos humanos mais qualificados e jovens do país e com uma classe média empobrecida e esvaída em impostos sem retorno socia efetivo. Uma revisitação do artigo $68^{\circ}$ e $68^{\circ}-A$ do Código do Imposto sobre o Rendimento das pessoas singulares (CIRS) e sua comparação com os níveis de taxação e escalões de tributação de outras legislações europeias homólogas. ${ }^{30}$

Ora, hoje é claro para as instituições europeias e para uma parte significativa dos investigadores dedicados a estas matérias, que a concorrência fiscal atual beneficia (tem beneficiado há décadas) alguns países da EU que se tornaram mais eficientes e produtivos com base na oferta de uma fiscalidade suave, com taxas de tributação mais baixas e benefícios fiscais muito agressivos, para captar investimento estrangeiro, confortáveis índices de concentração de capitais, tornando-se muito competitivos e mais desenvolvidos, do ponto de vista económico e social. Como já se deixou claro ao longo do que vem exposto, os países da EU que ocupam os lugares de destaque nos rankings internacionais de competitividade e crescimento são, precisamente os que têm uma fiscalidade mais baixa e atrativa.

Mesmo os países nórdicos, que apresentam níveis elevados de tributação direta sobre o rendimento de pessoas singulares, apresentam um conjunto de benefícios sociais e apoios à classe média que a compensam e justificam, e, ainda assim, conseguem oferecer uma tributação sobre o rendimento das empresas muito mais transparente e simples (sem tributações autónomas, desconsideração de custos e 
outros artifícios legais que destroem a confiança e credibilidade do país), o que os torna mais atrativos do que a maioria dos restantes países com fiscalidade assente em elevadas taxas de tributação. ${ }^{31}$

Os rankings que vão sendo divulgados pela AMECO/Comissão Europeia ${ }^{32}$, evidenciam a maior competitividade e melhor performance a todos os níveis dos países com melhor organização, "governance without corruption» e fiscalidade moderada. Neste contexto Portugal é, lamentavelmente, um mau exemplo de perda de competitividade e atratividade. Em todos os índices, crescimento do PIB, intensidade do capital n economia portuguesa, posição no ranking mundial de PIB per capita, crescimento desde a criação do euro e produtividade do trabalho, está entre as mais baixas da EU. Os resultados mais recentes evidenciam que apenas a Croácia, Eslováquia, Roménia, Hungria Letónia e Bulgária apresentam, em alguns índices, piores resultados do que Portugal.

\section{Impacto da concorrência fiscal sobre a competitividade}

Não se considera a concorrência fiscal no seio da EU um mal em si mesma. $\bigcirc$ que deixa subentender que na construção das bases jurídicas da EU nesta matéria se entendeu ser, por agora, impossível um grau de integração fiscal mais avançado. Seria ofender uma "área sagrada" da soberania dos Estados.

Porém, ao longo dos anos a concorrência fiscal acentuou-se e tornou-se, em alguns casos, uma realidade muito agressiva e acentuada com impacto discriminatório e muito negativo ao nível da competitividade das empresas. Daí a fuga das Multinacionais para se sediarem em determinados Estados da EU. Deslocação de empresas e fuga de rendimentos com afetação dos PIB de países com fiscalidade mais gravosa. A crise económica e financeira de 2008 e de 2011 acentuaram e evidenciaram este problema. (Anjos; Mimoso, 2021)

Os países que mais se destacam pela sua capacidade de captação de investimento externo, segundo a revisão de literatura efetuada, são o Luxemburgo, Irlanda, Países Baixos e Estónia. ${ }^{33}$

Após uma análise comparativa dos dados estatísticos tratados pela Comissão europeia e pelo World Competitiviness Ranking, concluímos que Portugal tem uma tributação sobre o rendimento das empresas que se situa entre os quatro países da EU com taxas mais elevadas de imposto. Acresce, ainda, o facto das regras de tributação em Portugal, serem mais complexas, e difíceis de entender com transparência pelo investidor estrangeiro.

Para além destes fatores em análise teremos também outros fatores próprios de cada país, que trazem mais valias para a angariação de um maior número de investimento

Segundo dados do Global Competitiviness Index, no qual se publicam anualmente os resultados da evolução dos países de todo o mundo em matéria de competitividade, destacamos a principal conclusão do Relatório:

«Europe displays regional strength in world competitiveness ranking while Singapore slips Innovation, digitalization, welfare benefits, and social cohesion are key to economic performance in the 2021 rankings, topped with Switzerland (1st), Sweden (2nd), Denmark (3rd), the Netherlands (4th), and Singapore (5th)- Top-performing economies are characterized by varying degrees of investment in innovation, diversified economic activities, and supportive public policy». ${ }^{34}$

Nos fatores, mencionados como determinantes no destaque dos mais elevados níveis de competitividade estão, precisamente, a inovação, a era digital, a par com o bem-estar social, coesão social e benefícios sociais.

Esta conclusão dos especialistas é particularmente relevante se aprofundarmos uma análise mais fina desses resultados. No topo dos países com maior nível de competitividade lidera a Suíça seguida dos países nórdicos. Deste grupo os segundos integram a EU e são, desde há décadas o bastião da real e efetiva social-democracia europeia. Os impostos são elevados para níveis de rendimento elevados, com garantia de gratuitidade total e universal para os serviços considerados essenciais aos cidadãos e à coesão social, essencial ao modelo nórdico. Quando comparamos os níveis de tributação entre estes países e Portugal ou qualquer outro país da EU, não podemos olhar apenas as taxas de imposto aplicáveis, pois é essencial conhecer os escalões de rendimento aos quais cada taxa se aplica e bem como as deduções pessoais admitidas.

Retornemos ao Relatório do $\mathrm{WCl}$, para extrair uma segunda conclusão muito importante: dos países da EU, a seguir aos países nórdicos vamos encontrar, por ordem descendente, a Holanda, Irlanda Luxemburgo. Esta análise, que relaciona o nível de competitividade de cada economia e o seu nível de tributação, evidencia que apresentam maior competitividade os países com menor tributação sobre o rendimento das empresas.

O ranking de competitividade é construído a partir da análise a nível global, e ilustra bem o quanto a União Europeia é desigual e heterogénea, sob o ponto de vista da competitividade e consequente desenvolvimento económico e social. O estudo evidencia o que vem exposto, pois apenas quatro países da EU se encontram entre os dez primeiros (TOP 10), a partir daí é notável a enorme disparidade entre os diferentes Estados membros da EU, ocupando posições muito distantes na tabela. ${ }^{35}$

De destacar, ainda, que os países no topo do ranking de competitividade se caracterizam por apresentar níveis de inflação e de corrupção muito reduzidos.

De notar, por último, que os resultados mais recentes apenas confirma o que diversos autores vêm salientando ao longo das últimas décadas: uma fiscalidade inadequada pode condenar a economia a perpetuar níveis de competitividade muito reduzidos, tendo por consequência uma espiral negativa e acentuada de ineficiência económica e social, com reflexo nas crises das finanças públicas, 
DOI: 10.46294/ulplr-rdulp.siv la7

com dívidas públicas crescentes, as quais por sua vez conduzem a mais e maior tributação, sobre as mais diversas fontes, alargando a base tributável muito para além das capacidades reais de cada país. Este círculo vicioso tem, inevitavelmente, como consequência o perpetuar do atraso no desenvolvimento económico e social dos países e da acentuação da pobreza e das disparidades sociais.

Lamentavelmente, Portugal encontra-se, desde há várias décadas aprisionado nesta realidade, deixando-se conduzir por uma fiscalidade prejudicial ao seu crescimento e desenvolvimento económico e social.

A concorrência fiscal no seio da EU é uma evidência, mas que ninguém parece querer alterar, porque alguns Estados membros têm alcançado melhores níveis de desenvolvimento, de crescimento económico e bem estar social, precisamente, por serem mais competitivos com base na fiscalidade moderada e atrativa que proporcionam às suas empresas e aos investidores estrangeiros (muitos dos quais são europeus provenientes de outros Estados membros com fiscalidade agressiva / opressiva sobre o rendimento das empresas e das famílias). Verdadeiramente, o problema é conhecido, mas a EU não tem conseguido superar a manifesta controvérsia ideológica subjacente.

Dito de outro modo, uma parte substancial dos Estados membros recusa enfrentar este problema por uma questão puramente ideológica, porquanto, a realidade mostra que os países com melhor Estado social, acabam por ser aqueles que apostaram numa fiscalidade «friendly» para o investimento económico. E, mesmo no caso dos países nórdicos, com uma fiscalidade elevada sobre o rendimento das pessoas singulares, não há dúvida que o Estado social existe e é garantido pelos elevados níveis de competitividade e emprego, com garantia de gratuitidade total dos «public utilities» essenciais para garantir a igualdade de oportunidades entre os cidadãos. Algo que, na larga maioria dos países com impostos mais elevados e agressivos não se encontra garantido, apesar do discurso político baseado na alegação da necessidade de impostos elevados para garantia do Estado social. Este discurso falacioso tem-se revelado útil para desculpabilizar governos incompetentes, corruptos, dominados por grupos de interesse que controlam as principais áreas de investimento público, cujo efeito multiplicador acaba anulado pelo peso da dívida pública que onera as gerações futuras e torna esses mesmos países pouco atrativos para os jovens mais qualificados.

Em suma, em nome do almejado Estado social desnata-se a riqueza das empresas e das famílias para sustentar um Estado ineficiente, que destrói riqueza e ao mesmo tempo põe em perigo o objetivo essencial da social-democracia ocidental: dotar cada indivíduo das competências necessárias para se realizar e alcançar - sucesso, individual e coletivo, por mérito próprio e em pleno gozo das suas liberdades individuais.

bem comum é um desiderato que se alcança, não à sombra de um qualquer Estado providencial, mas pelo esforço produtivo e mérito próprio de cada indivíduo, graças à igualdade de oportunidades garantida por um

efetivo Estado social. Não se trata de defender um Estado mínimo, mas antes de defender um Estado eficiente, o qual não deve falhar nos direitos fundamentais sociais (que alguns designam por direitos fundamentais de segunda geração) para garantir a igualdade de oportunidades: habitação, saúde, educação e formação e trabalho. Um Estado que não consiga garantir estes direitos sociais essenciais, falha totalmente na sua função social e coloca em perigo a própria essência da democracia.

A dura realidade mostra que é muito menos efetivo o Estado social existente nos países com fiscalidades elevadas (destrutivas de riqueza) do que nos Estados com fiscalidades mais contidas sobre o rendimento das empresas, focadas na competitividade e na construção de emprego bem remunerado, atraindo conhecimento e jovens qualificados. Enquanto este «fosso ideológico» não for ultrapassado, a EU não alcançará a almejada coesão económica e social e permanecerá em luta contra a desunião, consequência da desigualdade entre um grupo de países claramente mais desenvolvido e os restantes com problemas crónicos de má governação, dividas públicas elevadas e consequente evasão fiscal, erosão da base tributável em certas categorias de rendimento e opressão fiscal da classe média

Por tudo o que vem exposto, não temos dúvida que a EU tem muito mais a ganhar se avançar para uma fiscalidade cada vez mais harmonizada, que garanta uma concorrência efetiva e leal entre todos os Estados membros da EU. Porém, qualquer deliberação nesta matéria terá de ser aprovada por unanimidade, pelo que é necessário promover uma aproximação dos dois modelos em confronto na EU, tarefa difícil mas não impossível.

\section{Os efeitos da Pandemia COVID 19 na Política Fiscal na União Europeia}

Chegados aqui, importa refletir sobre os efeitos expectáveis decorrentes da pandemia COVID 19, no que respeita ao avanço na harmonização fiscal, com o

35

${ }^{5}$ Cfr. Relatório do World Competitiviness Ranking, disponivel em: https://www.imd.org/centers/world-competitiveness-center/rankings/world-competitiveness/. The Global Competitiviness Reporte 2019, divulgado peloWorld Economic Fórum, apresenta uma análise idêntica, evidenciando uma ligação óbvia entre a competitividade, o sistema fiscal, e a maior eficiência na concretização da desejada coesão económica e social - https://www3.weforum.org/docs/WEF_ TheGlobalCompetitivenessReport2019.pdf. 
propósito de combater a concorrência fiscal no seio dos países membros da UE. Como sabemos, o objetivo fundamental das regras de concorrência da UE é assegurar o bom funcionamento do mercado interno. Uma concorrência efetiva permite às empresas competir em pé de igualdade em todos os Estados-Membros, ao mesmo tempo que as pressiona a esforçarem-se continuamente por oferecer aos consumidores os melhores produtos aos melhores preços possíveis, o que, por sua vez, impulsiona a inovação e o crescimento económico a longo prazo.

A política de concorrência é, assim, um instrumento essencial para a realização de um mercado interno livre e dinâmico e para a promoção do bem-estar económico e social.

As mudanças sociais, económicas, geopolíticas e tecnológicas colocam constantemente novos desafios à política de concorrência da UE. Esses novos desenvolvimentos obrigam os decisores políticos a avaliar se o atual conjunto de instrumentos da política de concorrência continua a fornecer ferramentas eficazes para atingir o seu objetivo global, ou se terá de ser ajustado. Contudo, a pandemia emergente no final do ano 2019 na China e no primeiro trimestre de 2020 na Europa e no resto do mundo colocou um desafio sem precedentes. $\bigcirc$ impacto sobre as economias dos Estados membros foi (e ainda é) enorme, imprevisível. $\bigcirc$ maior desafio da EU desde a sua fundação.

A pandemia de COVID-19 colocou desafios específicos às empresas, aos consumidores e à economia no seu conjunto e exigiu uma série de medidas no domínio da concorrência, a fim de permitir uma resposta adequada a esses desafios. $\bigcirc$ exemplo mais evidente foi o regime de exceção em matéria de contratação pública, permitida a Portugal e em geral a todos os Estados membros, de modo a poder, rapidamente, prover aos bens e serviços necessários para enfrentar a pandemia, com dispensa de aplicação do regime do concurso público. Podemos dizer que UE tem tentado enfrentar os problemas emergentes da pandemia preservando o princípio da livre concorrência, mas sempre que necessário permitiu regimes de exceção para enfrentar a pandemia e prevenir futuras crises de saúde pública. Assim, a Comissão europeia propôs recentemente um conjunto de iniciativas destinadas a reforçar a autonomia estratégica da UE num contexto global, incentivando a prestação de serviços de saúde transfronteiriços em alinhamento com o regime da Diretiva 2011/24/EU. Mas há outras iniciativas a destacar, tais como, a proposta de um instrumento para fazer face aos potenciais efeitos de distorção das subvenções estrangeiras no mercado único e o previsto mecanismo de ajustamento carbónico fronteiriço da EU, entre outros. A EU continua, pois, atenta à preservação da livre concorrência no mercado da EU, nomeadamente, para evitar que as subvenções estatais voltem a instalar-se com o argumento da necessidade de fazer face à pandemia. A vertente preventiva dos instrumentos da política de concorrência abrange as regras em matéria de controlo das concentrações e auxílios estatais.

As regras em matéria de auxílios estatais destinam-se a impedir uma intervenção indevida do Estado sempre que um tratamento preferencial de determinados setores ou empresas falseie ou ameace falsear a concorrência e afete negativamente as trocas comerciais entre os Estados-Membros. Na sequência do surto da pandemia de COVID-19, a Comissão adotou, em abril de 2020, uma comunicação relativa a um "Quadro Temporário», que fornece orientações antitrust às empresas que cooperam para aumentar a produção e otimizar a oferta, em especial, de medicamentos hospitalares urgentemente necessários em resposta à crise.

Posto isto, considerando as medidas recentemente adotadas pela Comissão europeia podemos dizer que a estratégia de política fiscal da UE é explicada na comunicação designada «A política Fiscal da União Europeia - prioridades para os próximos anos". ${ }^{36}$

A análise do documento permite concluir as ideias cruciais da políitica fiscal para a EU pós pandemia, a saber:

a. o poder de introduzir, eliminar ou ajustar impostos continua nas mãos dos Estados-Membros;

b. desde que cumpra as normas da UE, cada Estado-Membro é livre de escolher o sistema fiscal que considere mais adequado;

c. neste âmbito, os Estados membros devem colaborar ativamente para alcançar as principais prioridades da política fiscal da UE para a próxima década, que são a eliminação dos obstáculos fiscais à atividade económica transfronteiras, o combate à concorrência fiscal nociva, à evasão fiscal e a promoção de uma maior cooperação entre as administrações fiscais no exercício do controlo e no combate à fraude;

d. uma coordenação redobrada da política fiscal de modo a assegurar que as políticas fiscais dos Estados membros apoiam os objetivos políticos mais gerais da UE, tal como definidos na "Estratégia 2020» ${ }^{37}$ para um crescimento inteligente, sustentável e inclusivo.

${ }^{36}$ Cfr. COM (2001) 260: Comunicação da Comissão ao Conselho, ao Parlamento Europev e ao Comité Económico e Social - A politica fiscal da União Europeia - prioridades para os próximos anos, disponível em: EUR-Lex - 164839 - EN - EURLex (europa.eu). 
Do que vem exposto, retiramos duas ideias cruciais, uma certamente positiva e uma negativa. A positiva consiste na constatação de ter sido inserido na agenda da Comissão europeia o tópico do combate à concorrência fiscal nociva, a qual é referida como objetivo prioritário face ao combate à evasão fiscal. Esta constatação afigura-se positiva na medida em que, pela primeira vez, a Comissão parece evidenciar a consciência de ser inútil o combate contra a evasão fiscal sem prévias medidas de combate à concorrência fiscal nociva. Até este documento estas duas frentes de combate apareciam em posição invertida com a evasão fiscal em destaque. Esta inversão no discurso pode ser um sinal muito positivo de uma tomada de consciência que não se alcançará bons resultados na luta contra a evasão fiscal se permitirmos que os Estados membros promovam, entre si, uma concorrência fiscal nociva aos interesses da EU.

A segunda ideia, profundamente negativa, é constatar que efetivamente não são delineadas quaisquer medidas para pôr termo à concorrência fiscal nociva. Aliás, o documento é manifestamente claro no reforço da soberania fiscal dos Estados membros. Assim sendo, permanece a dúvida de sempre: o que vai a EU fazer para combater a concorrência fiscal nociva?

A UE continua a apresentar nesta matéria um discurso muito programático, sem delineamento de instrumentos efetivos para o combate contra a concorrência fiscal nociva à coesão económica e social e a uma união efetiva entre os Estados membros. De notar que a introdução da discussão sobre a adoção de uma taxa mínima global de IRC, colocada na agenda pelo Presidente dos Estados Unidos da América, Joe Biden, chega ao plano internacional antes de ter sido equacionada no seio da UE. ${ }^{38}$

Este é um sinal claro do quanto a UE não conseguiu alcançar em matéria de harmonização fiscal. É lamentável que no seio da EU não tenha sido possível até hoje introduzir esta medida. Para alguns autores não há margem para avançar tendo em conta a posição dos Países Baixos, da Irlanda e do Luxemburgo. ${ }^{39}$

\section{CONCLUSÕES}

A concorrência fiscal no seio da UE é hoje uma realidade inegável e preocupante pelos efeitos nocivos sobre a livre concorrência. A UE não tem conseguido avançar no sentido de uma maior harmonização fiscal entre os seus Estados membros. Foram notáveis os resultados alcançados nas primeiras três décadas de integração económica, mas há muito que este processo foi estagnado pelas rivalidades internas e pela oposição de alguns Estados membros a uma maior harmonização das legislações em matéria fiscal.

A Comissão Europeia tem sido a única entidade que tem pressionado ao longo dos anos no sentido de adoção de medidas efetivas de aproximação da tributação em áreas muito específicas. $\bigcirc$ sucesso das suas iniciativas não tem sido notável e, sobretudo, não faz justiça ao esforço e insistência que tem incutido a este tópico. Acontece que, em matéria de fiscalidade, é preciso, segundo os tratados, unanimidade dos Estados-membros, o que torna praticamente impossível avançar nesta matéria

Na verdade, alguns Estados membros especializaram-se a fazer concorrência fiscal, ou seja, autêntico "dumping fiscal», o qual se tem revelado muito eficaz para garantir os elevados níveis de competitividade que as suas economias se mantenham competitivas e atraentes para a captação de capital e investimento estrangeiro. Deste modo alcançam resultados extraordinários em tempos de grandes dificuldades a nível global, pois não são apenas mais atraentes para - grande capital, mas também para os melhores recursos humanos disponíveis no espaço da UE. Dito de outro modo, aproveitam o melhor da UE enquanto espaço de liberdade de circulação de bens, serviços, pessoas e capitais, usando como principal ferramenta o sistema fiscal. Proporcionam taxas de tributação mais baixas, benefícios fiscais diversos e um sistema fiscal mais simples, transparente, estável e confiável.

A EU, como vimos, não tem responsabilidades diretas em matéria de cobrança de impostos nem da fixação das respetivas taxas. Cada governo nacional decide os impostos que os contribuintes devem pagar, assim como o modo como são gastas as receitas auferidas. $O$ poder de tributar está nas mãos dos Estados-Membros e a UE dispõe apenas de competências limitadas nesta matéria. Ora, sendo assim, é perfeitamente legitima a opção de certos Estados membros por soluções fiscais mais atrativas, tanto mais que têm conseguido garantir aos seus povos elevados

\footnotetext{
37 Ibidem. EUR-Lex - 164839 - EN - EUR-Lex (europa.eu).

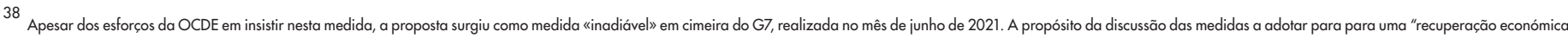

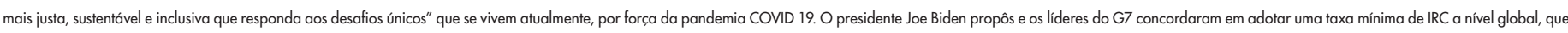

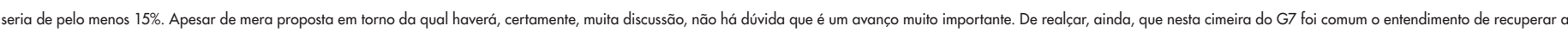

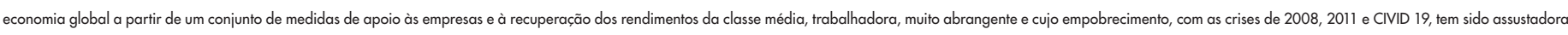
e coloca em perigo o modelo de democracia ocidental, fazendo proliferar correntes políticas populistas e extremistas que são uma ameaça real ao Estado de Direito Democrático.
} 
níveis de bem-estar social, apesar dos efeitos nocivos sobre a livre concorrência no mercado interno e todas as demais consequências daí resultantes. A rivalidade entre economias dos Estados membros tornou-se muito agressiva nas últimas décadas, prejudica a coesão económica e social e promove um divisionismo prejudicial ao futuro do projeto da EU.

A solução do problema é conhecida: maior harmonização fiscal no seio da UE. Mas avançar neste sentido implica consensos difíceis de obter entre Estados membros com realidades macroeconómicas e culturas políticas bem distintas.

Podemos concluir que no seio da UE se confrontam dois modelos ou ideais de organização política e social distintos. Convergem no objetivo comum de alcançar um Estado de Direito Democrático e Social, mas divergem profundamente quanto ao percurso a seguir para o alcançar. A visão sobre o melhor modelo de governação de modo a alcançar o "Welfare State» é algo em que nem sempre estão de acordo.

Por outro lado, há uma grande disparidade entre os pequenos e os grandes países que integram a UE. Estes últimos têm muito mais a perder com a concorrência fiscal desenvolvida por alguns Estados membros, de menor dimensão e que só desta forma têm conseguido manter bons níveis de competitividade e de desenvolvimento económico e social.

A harmonização da tributação indireta revelou-se uma preocupação desde a formação da Comunidade Económica Europeia, atual UE, com a adoção de um imposto sobre o valor acrescentado (IVA), moldado pela Diretiva IVA, pressuposto essencial para a admissão como Estados-membros. A explicação é simples e decorre da necessidade de harmonização em sede de tributação indireta para concretização do primeiro objetivo a atingir, ou seja, a livre circulação de bens. Mas mesmo nesta sede, muitas têm sido as dificuldades encontradas e numerosas as situações de incumprimento dos princípios firmados pela UE, cabendo ao Tribunal de Justiça da UE um papel fundamental na interpretação e compatibilização das normas de direito interno como direito da UE.

Já no campo da tributação direta os avanços foram muito lentos e, na verdade, pouco significativos. Privilegiou-se a harmonização do regime de tributação aplicável aos grupos de sociedades, como forma de facilitar a europeização de grupos económicos de maior relevo, regulando as suas relações com as sociedades suas afiliadas, de modo a incentivar o investimento estrangeiro entre os Estados membros.

Mas as diferenças de níveis de tributação, de benefícios fiscais concedidos e de regras aplicáveis à determinação da matéria tributável, continuam a ser um foco de diferenciação entre os Estados membros. Na verdade, desde há longas décadas se definiu muito claramente a existência de Estados membros da EU com fiscalidade mais favorável na comparação com os demais. A existência de «paraísos fiscais» dentro da EU tem gerado uma situação desigual e injusta no que toca à concorrência entre as empresas, o que se torna evidente, pela comparação dos níveis de tributação sobre o rendimento das empresas entre os Estados membros.

Portugal surge no topo da tabela com uma das taxas de IRC mais elevada dos países da Organização para a Cooperação e Desenvolvimento Económico (OCDE), contrariando a tendência de descida das taxas de tributação sobre o rendimento das empresas. Portugal precisa de enfrentar esta realidade e tornar a sua fiscalidade mais compatível com as suas necessidades de investimento estrangeiro e de criação de riqueza, de modo a tornar-se mais competitivo, reduzir os gastos públicos excessivos, concentrando os seus recursos na concretização dos direitos sociais determinantes para o sucesso individual e coletivo. ${ }^{40}$ Para isso, não pode deixar de acompanhar os seus parceiros europeus, nomeadamente no reconhecimento de benefícios fiscais e incentivos ao investimento estrangeiro com taxas reduzidas. ${ }^{41}$

Na ausência de uma efetiva harmonização fiscal no seio da EU Portugal não deve ignorar a sua condição real, e, por conseguinte, deve promover uma política fiscal orientada para captação de capital, investimento estrangeiro, know-how especializado e maior competitividade da sua economia.

A EU tem, definitivamente, de se reinventar e ser capaz de promover a harmonização fiscal essencial ao combate à concorrência fiscal nociva, respeitando as diferentes condições e especificidades de cada Estado membro, mas impondo regras de jogo transparentes, orientadas para uma efetiva coesão económica e social, de modo a combater o prenúncio de desintegração que se evidenciou na última década.

Concluímos, citando uma ideia recorrente em todos os relatórios da Comissão europeia sobre esta temática, que a UE precisa de promover a «fair taxation, it means, creating a fairer, more effective and more growth-friendly tax environment in the EU.»

39

Neste sentido, cfr., entre outros, Sørensen, P. B. (2001). Tax coordination in the European Union: What are the issues? SWEDISH ECONOMIC POLICY REVIEW, 8, 143-195, e Stoilova, D. (2017). Tax structure and economic growth: Evidence from the European Union. Contaduría y Administración.

40 Machová, Z., \& Kastan, M. (2010). tax burden in EU Countries - A Comparative study. Economic Sciences, 3, 263-270.

${ }^{41}$ Klemm, A. (2010). Causes, benefits, and risks of business tax incentives. International Tax and Public Finance, 17(3), 315-336. https://doi.org/10.1007/s10797-010-9135- 
DOI: 10.46294/ulplr-rdulp.sivla7

\section{Bibliografia}

Alena, A., Lucia, M., \& Slavomíra, M. (2017). Meta-analysis categorization of EU countries in the context of corporate income tax. Contaduría y Administración, 62(3), 1001-1018. https://doi.org/10.1016/i.cya.2017.04.002

Anjos, M. R. \& Mimoso, M. J. (2021) Free Competition in EU: Exploratory Study about Tax Benefits to Foreign Investment as a Distortion Measure of Free Competition. In Juridical Tribune, $n^{\circ} 1,2021$, págs. 38-48. Disponivel in http://hdll.handle.net/11328/3501. ISSN 2734-8830 (Online)

Anjos, M. R. (2021) Globalization, Fiscal Policy and Free competition: The impact in EU. The 20th International Scientific Conference Globalization and its Socio-Economic Consequences 2020. SHS Web of Conf. Economic Sustainability. Volume 92, 2021. DOI: https://doi.org/10.1051/shsconf/20219208001.

Anjos, M. R. (2019). Free Competition and Fiscal Policy in European Union. In D. Dukic, T. Studzieniecki \& J. Grzinic (Eds.), Economic and Social Development 49th International Scientific Conference on Economic and Social Development Development - "Building Resilient Society" (pp. 254-262). Varazdin: Varazdin Development and Entrepreneurship Agency. [Google Scholar]

Azizjaafar \& John, T. (2015). Tax Havens and Effective Tax Rates: An Analysis of Private versus Public European Firms. The International Journal of Accounting, 50(4), 435-457.

Bakija Jon \& Slemrod Joel. (2004). Do the rich from high state taxes? Evidence from federal estate tax returns (No. 10645), disponível: http://www.nber.org/papers/ w10645

Barna, Flavia \& Mura, P.-O. (2002). Recent developments in the UE Taxation. Young

Economists Journal, 9-19.

Bénassy- Quére, Agnès \& Fontagné, Lionel \& Lahrèche-Révil, A. (2005). How Does FDI. React to Corporate Taxation? International Tax and Public Finance, 12(5), 583-603.

Bevan, A. A., \& Estrin, S. (2004). The determinants of foreign direct investment into European transition economies. Journal of Comparative Economics, $32(4), 775-787$. https://doi.org/10.1016/i.jce.2004.08.006

Bretschger, Lucas \& Hettich, F. (2002). Globalisation, capital mobility and tax competition: theory and evidence for OECD countries. European Journal of Political Economy, 18(4), 495-716.

Bretschger, L., \& Hettich, F. (2002). Globalisation, capital mobility and tax competition: Theory and evidence for OECD countries. European Journal of Political Economy, 18(4), 695-716. https://doi.org/10.1016/S0176-2680(02)00115-5

Bucovetsky, S. \&, \& Wilson, J. D. (1991). Tax Competition with Two Instruments. 68, Regional Science and Urban Economics, 21, 333-350.

Buijink, W., Janssen, B. \& Schols, Y. (2002). Evidence of the effect of domicile on corporate average effective tax rates in the European Union. Journal of International Accounting, Auditing \& Taxation, $11(2), 115-130$.

Bustos-Contell, E., Climent-Serrano, S., \& Labatut-Serer, G. (2017). Offshoring in the European Union: a Study of the Evolution of the Tax Burden. Contemporary Economics, 11 (2), 235-248. https://doi.org/10.5709/ce.1897-9254.239

Claúdio Franchini (2007) Les notions d'administration indirecte, in Droit administratif européen, direcção de Jean - Bernard Auby e Jacqueline Dutheil de la Rochère, Bruylant, Bruxelas, págs. 245-246.

Csomós, B. \& Kiss, G. (2014). Evolution of the Hungarian Tax Structure after 2010. KözGazdaság, (4).

Delgado, F. J., Fernandez-Rodriguez, E., \& Martinez-Arias, A. (2014). Effective tax rates in corporate taxation: A quantile regression for the EU. Engineering Economics, 25(5), 487-496. https://doi.org/10.5755/j01.ee.25.5.4531

Devereux, M. P., Lockwood, B., \& Redoano, M. (2008). Do countries compete over corporate tax rates? Journal of Public Economics, 92(5-6), 1210-1235. https://doi. org/10.1016/i.jpubeco.2007.09.005 
Dyreng, S. D., Hanlon, M., Maydew, E. L., \& T., \& R., J. (2017). Changes in corporate effective tax rates over the past 25 years. Journal of Financial Economics, 124(3), 441-463. https://doi.org/10.1016/i.fineco.2017.04.001

Dzilalo, J. (2015). Tax Competition Or Tax Coordination? What Is Better For The European Union? Comparative Economic Research, 18(2), $37-55$.

European commission. (2015). A Fair and Efficient Corporate Tax System in the European Union: 5 Key Areas for Action.

European Commission. (2015). Communication from the Commission to the European

European Commission Report -https://europa.eu/european-union/topics/taxation.pt

European report of Parliament and the Council on a Fair and Efficient Corporate Tax System in the European Union: 5 Key Areas for Action \{COM(2015) 302 final\}.

European Commission (2001). COM (2001) 260: Comunicação da Comissão ao Conselho, ao Parlamento Europeu e ao Comité Económico e Social - A política fiscal da União Europeia - prioridades para os próximos anos, disponível em: EUR-Lex - 164839 - EN - EUR-Lex (europa.eu)

European Economic and Social Committee (2021) «Plano de ação para uma tributação justa e simples que apoie a estratégia de recuperação» [COM(2020) 312 final] Jornal Oficial da EU de 30-04-2021

Frenkel, J., Razin, A. \& Sadka, E. (1991). International taxation in an integrated world. Cambridge: MIT Press., 315-319.

Gravelle, J. (2013). Tax havens: International tax avoidance and evasion. Congressional, Research Service, CRS Report for Congress.

Hodžið, S. (2011). Harmonization of corporate tax general guidelines in the UE and harmonization in Germany, Austria and Italy. Our Economy (Nase Gospodarstvo), $58(1), 64-71$.

Haan, J., Sturm, J. (1994). The Political and Institutional Constraints of Fiscal Policy in the European Union. Public Choice Review, 80(1-2), $157-172$.

Janssen, B. (2005). Corporate effective tax rates in the Netherlands. Economist, 153(1), 47-66. https://doi.org/10.1007/s10645-004-7127-y

Klemm, A. (2010). Causes, benefits, and risks of business tax incentives. International Tax and Public Finance, 17/3), 315-336. https://doi.org/10.1007/s10797-0109135

Krajnak, M. (2019). Do Selected Tax Advantages Affect Tax Revenue from the Personal Income Tax? Journal of Competitiveness, 11(4), $73-88$.

Laura-Liana, S., \& Carmen, M. A. (2009). The Flat Tax Effects - Theoretical and Empirical Evidence in Western and Eastern European Countries. Annals of Faculty of Economics, vol.3, 343-348

Machová, Z., \& Kastan, M. (2010). tax burden in EU Countries - A Comparative study. Economic Sciences, 3, 263-270.

Mateus, A. M. (2000). A Competitividade Fiscal no Contexto da União Europeia. Universidade Nova de Lisboa. Retrieved from. https://home.kpmg.com/pt/en/home/ services/tax/tax-tools-and-resources/tax

Mendoza, G. E. \& Razin, Assaf \& Tesar, L. L. (1994). Effective tax rates in macroeconomics: Cross-country estimates of tax rates on factor incomes and consumption. Journal of Monetary Economics, 34(3), 297-323.

Monagha (2012). Attraction and Retention of Foreign Direct Investment (FDI): The Role of Subnational Institutions in a Small, Highly Globalised Economy. Irish Journal of Management.

Myyra, S., Pouta, E., \& Pietola, K. (2011). The Effects of Changes in Capital Gains Taxes on Land Sales : Empirical Evidence from Finland. Land Economics (Vol. 87). 73 Neumann, Rebecca \& Holman, Jill \& Alm, J. (2009). Globalization and tax policy. The North American Journal of Economics and Finance, 20 (2), 193-211.

Nevado, P. (2002). A opção expatriado-local na gestão de topo das subsidiárias das empresas multinacionais. $\bigcirc$ caso das subsidiárias portuguesas de empresas alemãs.

Overesch, M. \& Rincke, J. (2011). What drives corporate tax rates down? A reassessment of globalization, tax competition, and dynamic adjustment to shocks. The 
DOI: 10.46294/ulplr-rdulp.siv la7

Scandinavian Journal of Economics, 113(3), 579-602.

Rubinger, J. (2011). Will Malta Become the "New" Ireland in International Tax Planning? The Florida Bar Journal, (March).

Russu, C. (2016). Foreign Direct Investment in the European Union. Economic Insights. Trends and Challenges, 5(1), 51-63.

Schwab, K. (2017). The Global Competitiveness Report 2017-2018. World Economic Forum (Vol. 5). https://doi.org/92-95044-35-5

Sørensen, P. B. (2001). Tax coordination in the European Union: What are the issues? SWEDISH ECONOMIC POLICY REVIEW, 8, $143-195$.

Sørensen, P. B. (2009). Dual Income Taxes: A Nordic Tax System. University of Copenhagen, Economic Policy, 2009-10, 1-34.

Spengel, C., \& Wiegard, W. (2004). Dual Income Tax: A Pragmatic Tax Reform Alternative for Germany. Ifo Institute - Leibniz Institute for Economic Research at the University of Munich, 02(3), 15-22

Stoilova, D. (2017). Tax structure and economic growth: Evidence from the European Union. Contaduría y Administración.

Sulimana, A. H., Elianb, M. I., \& Alic, H. E. (2018). Endogenous Specification of FDI and Economic Growth : Cross-Economies ' Evidence. Internation Journal of Business, 23-39.

Verhoeven (1983) Communauté Européennes et Rapprochement dês Legislations, Bruxelas, 1983

Waelbroeck. (1986) L'Harmonisation dês Régles et Normes Techniques dans la CEE, Doctrine, Bruxelas

World Competitiviness Ranking (2020) Annual Report. Available: https://www.imd.org/centers/world-competitiveness-center/rankings/worldcompetitiveness/.

Zimler, J. (2007) "Introduction: les concepts d'administration directe, d'administration indirecte et de co-administration et les fondements du droit administrative européen", in Droit administratif européen, direcção de Jean Bernard Auby e Jacqueline Dutheil de la Rochère, Bruylant, Bruxelas 